Erg. inn. Med. 10, 531 (1913). - 13. AlDER, A. Handbuch der norm. und pathol. Physiologie von A. Bethe und G. von Bergmann, Bd. VI, 1. Hälfte, S. 534, Berlin (1928). - 14. LoEwe, F., Optische Messungen des Chemikers und des Mediziners. 5. Aufl., Th. Steinkopff, Dresden und Leipzig (1949). - 15. Rrva, G., Das Serumeiweißbild. S. 176ff., 1. Aufl., Huber, Bern-Stuttgart (1957). - 16. Weber, E., Grundriß der biologischen Statistik, 5. Aufl.,
VEB G. Fischer Verlag, Jena (1964). - 17. Doerfel, K., Statistik in der analytischen Chemie, 1. Aufl., VEB Deutscher Verlag für Grundstoffindustrie, Leipzig (1966). - 18. Wissenschaftliche Tabellen, Documenta Geigy, 6. Aufl., Basel (1960). - 19. Heusser, H. und J. Scrineider, Schweiz. Med. Wschr. 77, 1327 (1947).
Priv. Doz. Dr. Dr. D. Stamm 8 München 23

Kraepelinstr. 10

\title{
Some Abnormal Permeability Characteristics of Ehrlich Ascites Tumor Cells ')
}

\author{
By L. A. KIEsow \\ Division of Molecular Energetics, Bioenergetics Laboratories, Naval Medical Research Institute, Bethesda, Maryland 20014, \\ U. S. A.
}

(Eingegangen am 11. April 1968)

Dedicated to Ernst Sabiitte on the occasion of bis 60 th birtbday

The intracellular and extracellular distribution of inorganic phosphate was studied with Ehrlich ascites tumor cells and trypsinized kidney cortex cells. Both, the intracellular and also the extracellular concentrations of inorganic phosphate were varied experimentally. The reported data suggests abnormal permeability characteristics of the Ehrlich ascites tumor cell.

Die intra- und extrazelluläre Verteilung von anorganischem Phosphat wurde an Ehrlich-Ascites-Tumorzellen und trypsinierten Nierenrindenzellen untersucht. Sowohl intra- als auch extrazelluläre Phosphatkonzentration wurden im Versuch variiert. Die Ergebnisse zeigen ein anormales Permeabilitätsverhalten der Ehrlich-Ascites-Tumorzelle.

There is little doubt that to establish permeability barriers is one of the foremost. functions of the cell membrane. To provide the membrane with such capabilities, the chemical nature of the permeating molecule and the structural and chemical nature of the cell membrane are acting in concert thereby permitting the cell to maintain a controlled interior milieu. It is furthermore well-known that a number of cellular enzymes support the membrane in this performance. Such is, for example, achieved by the intracellular introduction of a charged group into a previously uncharged molecule whereby it is rendered greatly impermeable after it entered the cell.

Nevertheless, exceptions to this general function of cell membranes have been described in the past. It was shown that even enzymatically active proteins, like aldolase (EC 4.1.2.13) may be released by certain cells $(1,2)$. Moreoxer, molecules like $\mathrm{NADH}$ were demonstrated to effectively interact on the site of intracellular enzymes when added extracellularly and to thereby influence metabolic rates like the rate of glycolysis (3). More recently the lack of membrane permeability barriers of certain intracellular parasites was shown to be one of their most outstanding features permitting these organisms to easily utilize metabolites, energy donors, and coenzymes provided by the host cell (4). This is a striking example, indeed, since it indicates how permeability characteristics of cellular membranes may gain control over metabolic patterns

1) The experiments reported herein had been concluded by December 1961 at the Physiologisch-Chemisches Institut der Freien Universität Berlin. and metabolic rates of both the intracellular parasite and the host cell as well. This relationship between a parasite and its host is mainly caused by the mutual exchange of metabolites and metabolic end products and it affects the metabolism of both the parasite and the host cell quite drastically. Such a relationship may not only permit the growth of the parasite but it may also destroy the host cell at the same time.

It becomes therefore quite apparent that the peculiarities of cell membranes safeguard an individual cell, thus permitting it to maintain distinct intracellular conditions. If, however, the membrane fails in this function or if some membrane characteristics are altered in a way that it no longer can perform this task, it inevitably exposes the cell's interior to influences of the exterior environment. Hence, any cell with a failing membrane will more or less have to adapt to or will be affected by the metabolite concentration and the ionic composition of the extracellular fluid prevailing in the organ in which this event occurs.

Some unusual features which may indicate abnormal permeability characteristics of the cell membrane of Ehrlich ascites tumor cells shall be reported in this paper. The experiments described herein pertain primarily to the permeation of the inorganic phosphate ion. They were executed mainly for three reasons:

(1) the permeation of phosphate ions will necessarily show many phenomena common to all such processes that involve ionized molecules or ions per se.

(2) the inorganic phosphate ion is known to exert considerable metabolic control within the cell involving individual enzymes and consequently metabolic pathways like glycolysis $(5,6)$ and cell respiration $(7)$. 
(3) through the use of 2-deoxy-D-glucose, the inorganic phosphate concentration of intact cells becomes manageable and assessable to experimentation (8). It can, for instance, be lowered by a simple extracellular addition of this sugar.

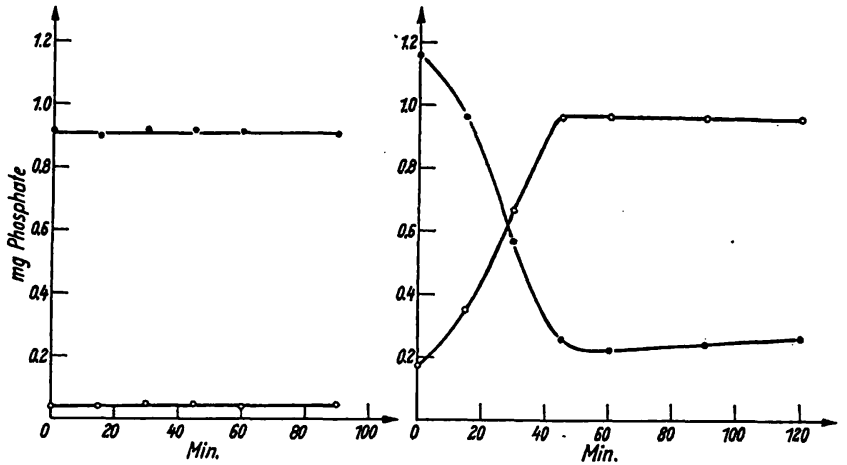

Fig. $1 \mathrm{a}$ and $1 \mathrm{~b}$

The distribution of inorganic phosphate between medium and kidney cortex cells ( 1 a) and Ehrlich ascites tumor cells (1b).

Both kinds of cells were suspended in $0.8 \% \mathrm{NaCl}$ containing $2 \mathrm{mg}$ sodium lactate per $\mathrm{ml}$. Samples were taken periodically and phosphate was determined as described under methods. The ordinate indicates the $\mathrm{mg}$ of phosphate per $1 \mathrm{ml}$ of cell volume (--) or per corresponding medium volume $(0-0)$. respectively. The absolute concentrations of inorganic phosphate per $1 \mathrm{ml}$ medium (in $1 \mathrm{~b}$ ) were minutes. details are described in the chapter on methods

\section{Results}

In the experiment shown in Figure $1 \mathrm{a}$ and $\mathrm{b}$, two homogenous cell suspensions, one consisting of Ehrlich ascites tumor cells of mice, the other of trypsinized mouse kidney cells are submitted to aerobic incubation in phosphate free isotonic saline solutions. Both suspensions are sampled periodically and the samples are analyzed for the intracellular and extracellular distribution of inorganic phosphate. A rather striking difference between the two cell suspensions can be observed. The kidney cells maintain a rather constant intracellular level of inorganic phosphate without any significant loss of phosphate to the medium. The suspension of Ehrlich ascites tumor cells, however, responds quite differently; i. e., inorganic phosphate is released by the cells to appear in the suspension medium. It can also be seen how this process after an initially rapid phosphate exchange approaches a level which apparently reflects equilibrium distribution of inorganic phosphate between cells and medium. While kidney cells can evidently maintain an intracellular phosphate concentration, independently from direction and magnitude of the concentration gradient of inorganic phosphate, Ehrlich ascites tumor cells can not. Quite to the contrary, they are releasing inorganic phosphate from the intracellular space into the suspension medium thereby following the existing concentration gradient.

The interpretation of the experiments shown in Figure 1 is strengthened by the experimental design of Figure 2 where inorganic phosphate is added in increasing concentrations to a medium in which Ehrlich ascites tumor cells are suspended. Again, a release of inorganic phosphate by the cells can be observed and again, this phos-
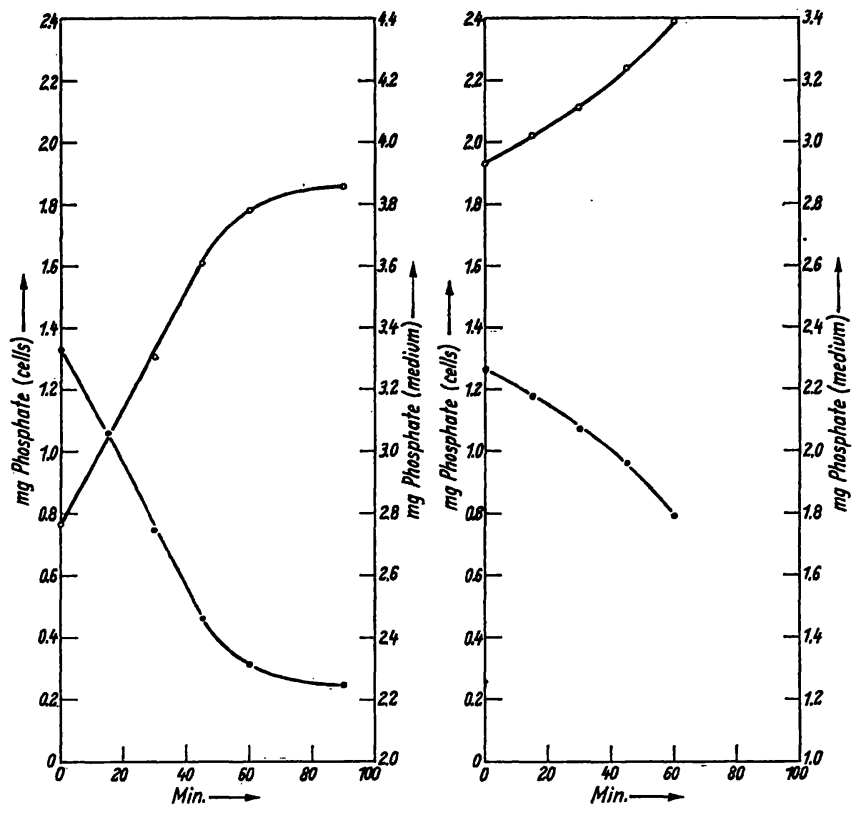

Fig. $2 a$ and $2 b$

The effects of extracellular phosphate on the release of inorganic phosphate by ascites tumor cells

The experimental design was similar to figure 1 with the exception that $1 \mathrm{ml}$ of medium contained at 0 minutes incubation time either $0.2 \mathrm{mg}$ phosphate $(2 \mathrm{a})$ or $0.5 \mathrm{mg}$ phosphate $(2 \mathrm{~b})$. The left ordinates represent the mg phosphate per $1 \mathrm{ml}$ of cells (--*); the right ordinates of cells $(0-0)$. The abscissas are the time in minutes

phate appears extracellularly in the medium. However, increasing concentrations of added inorganic phosphate tend to decrease the initial speed of the release of phosphate by the cells as indicated by the decrease of the initial slope. This phenomenon is to be expected if the concentration gradient of inorganic phosphate alone determines both the direction and the velocity of phosphate flux.

To further prove this assumption, use was made of an earlier observation showing that the intracellular inorganic phosphate of Ehrlich ascites tumor cells can be affected experimentally through the extracellular addition of 2-deoxy-D-glucose. 2-DOG' ${ }^{2}$ is known to be metabolized by Ehrlich ascites tumor cells only to a limited extent. That is to say, only the initial step of glucose metabolism, the phosphorylation of glucose by ATP in the hexokinase reaction, is utilized in the metabolism of 2-DOG. This step results in a: phosphorylation of 2-DOG. Yet, intracellular inorganic phosphate is also required, since it is utilized in the respiratory chain phosphorylation of ADP resulting in ATP formation. The ATP serves subsequently as a phosphate donor in the hexokinase reaction. This sequence of enzymatically catalyzed events, together with the fact that glucose-6phosphatase (EC 3.1.3.9) is essentially absent in Ehrlich ascites tumor cells, results in a substantial accumulation of 2-deoxy-glucose-6-phosphate. As can be seen from figure 3 , considerable amounts of the intracellularly available inorganic phosphate are trapped by the accumulating deoxy-glucose-6-phosphate. A simple comparison between figure 3 and figures 1 and 2

2) 2-DOG $=2$-deoxy-D-glucose 


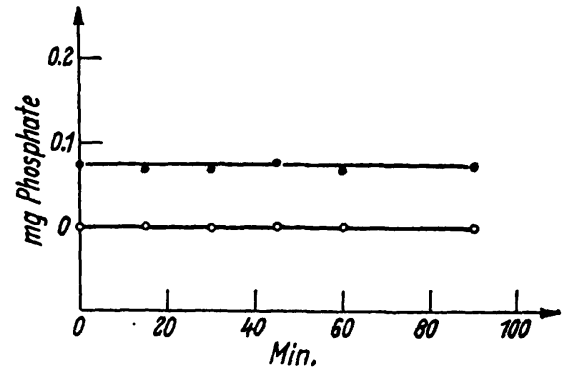

Fig. 3

The decrease of the intracellular inorganic phosphate of ascites tumor cells by 2 -deoxy-D-glucose

The experimental conditions were identical with those of figure 1 . However, prior to the determination of phosphate distribution the intracellular inorganic phosphate was bound by $20 \mathrm{~min}$. preincubation with $2 \mathrm{mg} 2-D O G$ per $1 \mathrm{ml}$ of medium. Ordinate: $\mathrm{mg}$ phosphate per $1 \mathrm{ml}$ of cells $(-\infty)$ or corresponding medium volume $(\bullet-0)$; abscissa time in minutes

indicates that the reaction sequence initiated by the 2ddition of 2-DOG decreases inorganic phosphate within the cells by almost one order of magnitude.

For the purpose of this paper, however, the 2-DOG technique permits a reversal of an existing concentration gradient of inorganic phosphate. In addition, the characteristics of the cell membranes of Ehrlich ascites tumor cells appear to be such that ions like inorganic phosphate can penetrate it relatively freely following only the direction of the existing concentration gradient. A reversal of the concentration gradient of inorganic phosphate by 2-DOG should therefore cause extracellularly available phosphate to flow through the cell membrane into the cell.

An experiment of this kind is shown in figure 4 . The intracellular inorganic phosphate concentration of Ehrlich ascites tumor cells was initially lowered by the addition of $2 \mathrm{mg}$ 2-DOG per $\mathrm{ml}$ of cell suspension. It

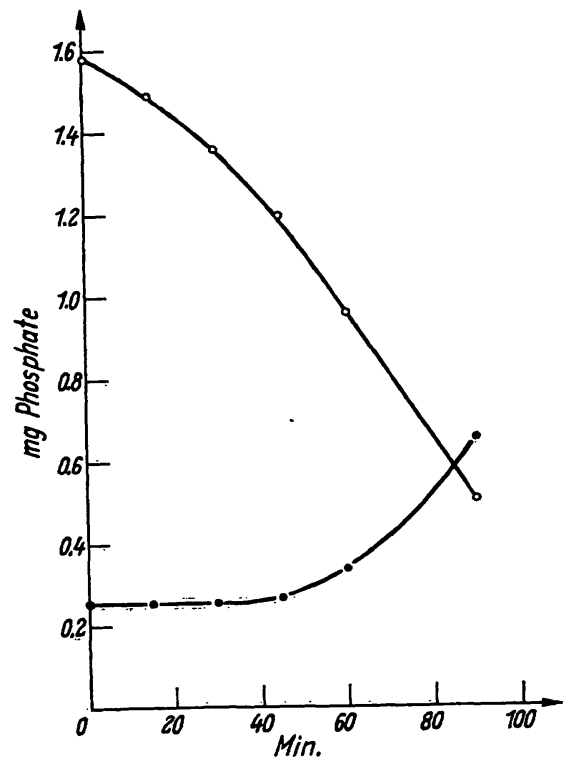

Fig. 4

The influx of extracellular inorganic phosphate into ascites tumor cells with experimentally lowered intracellular phosphate

The experimental design was identical with the one of figure 3. At 0 time $0.2 \mathrm{mg}$ phosphate were added per $1 \mathrm{ml}$ of medium. The ordinate represents the mg phosphate per $1 \mathrm{ml}$ of cells (--) or the correrepresents the ming polume (o- 0 ) respectively. The abscissa is the sponding medium volume $(\circ-0)$ respectiv can be seen that the addition of 2-DOG not only lowers the intracellular inorganic phosphate concentration but causes inorganic phosphate to penetrate through the cell membrane from the medium into the cell. It may be surprising not to see an initial increase of intracellular inorganic phosphate, since the phosphate concentration of the medium is lowered rather promptly. This, however, is explained by the considerable amounts of inorganic phosphate that can be trapped by an excess of 2-DOG as 2-deoxy-glucose-6-phosphate. Only after the available 2-DOG is exhausted, the intracellular inorganic phosphat concentration will rise.

To further substantiate this interpretation, limiting amounts of 2-DOG have been used in the experiments shown in figure 5 . With limiting concentrations of 2-DOG its capacity to bind inorganic phosphate is necessarily also limited. Such a 2-DOG addition to Ehrlich ascites tumor cells will therefore cause the inorganic phosphate of the medium to decrease readily. This time, however, due to the reduced trapping capacity, intracellular inorganic phosphate will increase much earlier.

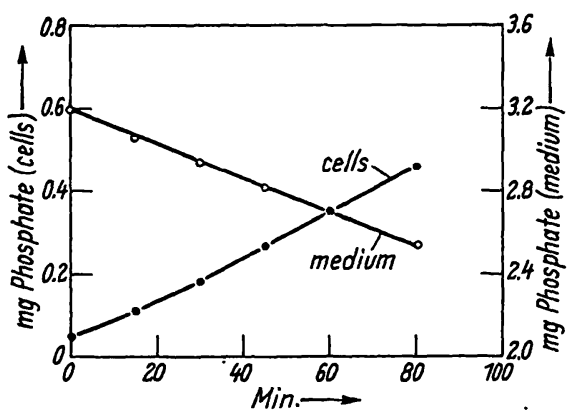

Fig. 5

The influx of extracellular inorganic phosphate into ascites tumor cells with experimentally lowered intracellular phosphate but limiting concentrations of 2-deoxy-D-glucose

The experimental conditions were identical with those of Figure 4. However, only $0.4 \mathrm{mg} \mathrm{2-DOG}$ per $\mathrm{ml}$ of medium were added during preincubation. Left ordinate: $\mathrm{mg}$ phosphate per $1 \mathrm{ml}$ cells $(\bullet-\bullet)$ right ordinate: $\mathrm{mg}$ phosphate per medium volume that corres
with $1 \mathrm{ml}$ of cells $(\circ-0)$; abscissa: time in minutes

\section{Discussion}

The experiments described herein pertain to the permeation of the inorganic phosphate ion from the intracellular to the extracellular space and vice versa. They bear out certain characteristics of the cell membrane of Ehrlich ascites tumor cells which are unusual. These cells evidently permit the inorganic phosphate to distribute quite freely between the extracellular and the intracellular space whereby the phosphate follows only the direction of the existing concentration gradient. Consequently, if a cell showing such membrane characteristics is exposed to low extracellular inorganic phosphate concentrations, it will loseinorganic phosphate until equilibrium is established. If, however, the same cell is exposed to high inorganic phosphate concentrations in the extracellular fluid, it will gain inorganic phosphate until it reaches equilibrium.

The phosphorylation of 2-DOG may serve as a model of metabolic reactions which due to phosphorylations 
depend either directly or indirectly on inorganic phosphate. 2-DOG can, therefore, simulate a phosphate demanding metabolic pathway which would otherwise also result in a similar decrease of the intracellular inorganic phosphate (7). The experiments shown in figures 4 and 5 indicate that in the case of ascites tumor cells such a requirement can even be fulfilled by inorganic phosphate originating from the extracellular medium. While normal tissue cells have apparently only limited access to extracellular phosphate, ascites tumor cells do not have such limitations. Here the phosphate requirement can be fulfilled quite easily because of the relative freedom with which phosphate penetrates the membrane in the direction of the newly established concentration gradient. If, however, the demand for inorganic phosphate is limited by reduced cellular metabolic activities, Ehrlich ascites tumor cells will for the same reason lose inorganic phosphate whenever the extracellular concentration of this ion is low which it usually is. In other words, Ehrlich ascites tumor cells will always tend to equilibrate with the inorganic phosphate of the extracellular environment.

This is a significant result. It is especially so in view of the experiment described in figure 1. There it was shown that normal tissue cells do not release inorganic phosphate as freely as Ehrlich ascites tumor cells and do not tend to achieve phosphate equilibrium. A kidney cortex cell suspension does not lose intracellular inorganic phosphate to the medium but it maintains independently a rather welldefined intracellular level of inorganic phosphate. Ehrlich ascites tumor cells, however, being submitted to otherwise identical conditions, are losing inorganic phosphate until equilibrium with the extracellular fluid is reached. They are, therefore, cells which are to a certain extent open and which may, due to abnormal membrane characteristics, easily lose as well as easily gain inorganic phosphate depending on whatever is required to obtain equilibrium distribution of this ion.

One may raise the question whether or not the inorganic phosphate ion is in that respect representative of a larger group of ionic molecules and ions. In view of other data quoted in the literature $(1,2,3)$ and in view of the structure of the phosphate ion, one may be willing to admit this. It is very likely that in the case of Ehrlich ascites tumor cells the phosphate ion shares its unusual permeation characteristics with other ions. This is, however, only rarely possible to prove since the 2-DOG method applies only to phosphate. Even with normal tissue cells which phosphorylate 2-DOG only very slowly (9) this method is of little help and consequently no appreciable decrease of intracellular phosphate can be achieved.

The inorganic phosphate ion features an additional characteristic; that is, its ability to exert metabolic control. Glycolysis and respiration, for instance, have both been shown to depend strongly on the cellular phosphate concentration $(10,5,6,7)$. This is due to phosphate requirements of the participating phosphory- lating enzymes. Inorganic phosphate, however, will also affect the pool size of phosphorylated intermediates. These too depend strongly on the intracellular availability of inorganic phosphate. Due to the abnormal permeability characteristics of the cell membrane of Ehrlich ascites tumor cells, as reported in this paper, this kind of phosphate requirement can, of course, also be satisfied quite efficiently. Especially in this context one should bear in mind that high cellular concentrations of several glycolytic intermediates are prerequisites for a number of synthetic processes of tumor cells.

Evidently, the abnormal permeability characteristics of Ehrlich ascites tumor cells, as described here for the inorganic phosphate ion, may have several implications concerning the metabolism of such cells. How general they are remains to be shown with other cells in the future.

\section{Methods}

\section{Ebrlich Ascites Tumor Cells}

Six-day old Ehrlich ascites tumor cells were used throughout these experiments. $0.25 \mathrm{~m} /$ of cell containing ascites fluid served for the inoculation of inbred white mice of the NMRI strain. The freshly harvested ascites fluid was separated into plasma and cells by centrifugation. Ascites, containing blood cells was discarded. The packed cells were then resuspended in isotonic saline solutions or in inactivated ascites serum. They were washed twice by centrifugation and diluted with suspension medium to the desired final concentration.

\section{Trypsinized Tissue Cells}

Kidneys were removed from mice immediately after decapitation. They were freed from connective tissue and fat. Only the kidney cortex was removed and was minced in a solution containing $8.0 \mathrm{~g} \mathrm{NaCl} ; 0.2 \mathrm{~g} \mathrm{KCl} ; 1.15 \mathrm{~g} \mathrm{Na}_{2} \mathrm{HPO}_{4}+2 \mathrm{H}_{2} \mathrm{O} ; 0.2 \mathrm{~g} \mathrm{KH}_{2} \mathrm{PO}_{4}$; $0.1 \mathrm{~g} \mathrm{MgCl}+6 \mathrm{H}_{2} \mathrm{O}$ and $2.5 \mathrm{~g}$ trypsine (Difco 1:250) per one liter of glass distilled water. The minced tissue was stirred in this solution at $25^{\circ} \mathrm{C}$ and the supernatant removed every half hour and replaced by fresh medium. The cell suspension thus obtained was immediately chilled and the cells removed by centrifugation at low speed. The cell pellets were resuspended in either saline solutions or inactivated ascites serum and were washed three times by centrifugation. Finally, the cells were resuspended in the desired medium and diluted to the desired final concentration.

\section{Inactivated Ascites Serum}

Ascites fluid of mice containing Ehrlich ascites tumor cells was harvested ten days after inoculation. The cells were removed by centrifugation and the supernatant serum was kept at $58^{\circ} \mathrm{C}$ for ten minutes. An occasionally forming turbidity was removed by centrifugation.

\section{Incubation}

Special flasks agitated in a metabolic shaker at $38^{\circ} \mathrm{C}$ served for all incubations. They were shaped like Erlenmeyer flasks with an approximate volume of $40 \mathrm{ml}$. A $15 \mathrm{~cm}$ long glass capillary tube was fused to the neck, permitting only gas diffusion, thus making incubations possible with a defined gas atmosphere in an essentially open flask. It was therefore simple to withdraw samples and to make additions. If the cells were suspended in saline solution without bicarbonate, the gas phase consisted of air. If the cells were suspended in inactivated ascites serum or bicarbonate containing saline, the gas phase consisted of 5 vol. $\% \mathrm{CO}_{2}$ in air. Each experiment reported in the chapter on results was repeated at least five times. 


\section{Pbosphate Analysis}

Phosphate was analyzed according to the method described in "Photometrical Methods for the Eppendorf Photometer" (11). This method proved superior to all other methods of phosphate analysis previously employed.

\section{Measurement of the Intracellular and Extracellular Distribution of Inorganic Phosphate}

Aliquots of the cell suspension were quickly removed at various times during the incubations. One-half of each aliquot was subjected directly to phosphate analysis. The other half was rapidly separated into packed cells and a cell-free supernatant by means of a specially built microcentrifuge. This centrifuge permitted complete separation in less than a minute. The supernatant thus obtained was also analyzed for inorganic phosphate. Two values for inorganic phosphate were thereby obtained - one of which representing the total inorganic phosphate of cells plus suspension medium. The other value represented the inorganic phosphate content of the suspension medium alone. Simple substraction of the second value from the first one permitted to obtain the inorganic phosphate of the cells as the difference between the two. To calculate the cellular concentration of inorganic phosphate additional data on the cell volume was required. The cell volume was determined by centrifugation in special cytocrit tubes and it was read after the packed cell volume became constant.

Since any volume of packed cells contains a certain amount of medium, a correction considering this volume was required. This volume was obtained from the literature (12) and it attributes to approximately $18 \%$ of the packed cell volume as determined by the cytocrit technique. All values of inorganic phosphate plotted in the diagrams have therefore been corrected for this $18 \%$ difference.

All plots in this paper represent the inorganic phosphate concentration of $1 \mathrm{ml}$ of packed cells and of the corresponding medium volume in which $1 \mathrm{ml}$ of packed cells was suspended.

\title{
References
}

1. WARBURG, O. and E. Hiepler, Z. Naturforsch. $7 b, 193$ (1952). 2. Warburg, O., K. GaweHN and G. LaNGe, Z. Naturforsch. 9b, 109 (1954). - 3. Woods, M. and D. Burk, Z. Naturforsch. 186, 731 (1963). - 4. WeIss, E., J. Bact. (Baltimore) 90, 243 (1965). 5. LYNEN, F., Liebigs Ann. Chem. 546, 120 (1941). - 6. Johnson, M. J., Science (New York) 94, 200 (1941). - 7. Kinsow, L., Z. Naturforsch. 16b, 567 (1961). - 8. Kresow, L., Z. Naturforsch. 16b, 32 (1961). - 9. KIESOw, L., Z. Naturforsch. 15b, 487 (1960) 10. Warburg, O. and W. Christian, Biochem. Z. 303, 40 (1939). - 11. in: „Photometrische Methoden zum Photometer Eppendorf", Netheler and Hinz, Hamburg (1960). - 12. Rice M. E. and E. Shelton, J. Nat. Cancer Inst., Wash., 21, 961 (1954).

\section{Lutz A. Kiesow}

Naval Med. Res. Inst.

Bethesda, Maryland 20014, USA

\section{Immunchemische Untersuchungen an Carboxylesterasen}

\author{
Von P. HAIN ${ }^{1}$ ) und K. KRISCH \\ Aus dem Pbysiologisch-Chemischen Institut der Universität Giessen
}

(Eingegangen am 16. April 1968)

\section{Herrn Prof. Dr. Dr. Ernst Schütte in Verebrung zum 60. Geburtstag genvidmet}

Es wird über immunchemische Untersuchungen (Doppeldiffusion nach OuchreRLONY, Immunelektrophorese) von drei hochgereinigten Carboxylesterasen (EC 3.1.1.1) verschiedener Herkunft (aus Schweineleber, Schweineniere und Rinderleber) berichtet. Durch Immunisierung von Kaninchen wurden Antiseren gegen Schweineleber- und Schweinenierenenzym erhalten. Schweineleberesterase verhält sich immunologisch einheitlich, während Schweinenierenesterase noch Spuren von mindestens zwei Fremdkomponenten erkennen läßt. Schweinelebetr- und Schweinenierenesterase verhalten sich im Ouchterlony-Test immunologisch identisch, unterscheiden sich jedoch quantitativ im Präzipitationsversuch mit steigenden Antigenkonzentrationen. Rinderleberesterase reagierte im vergleichenden Doppeldiffusionsversuch mit Antiserum gegen Schweineleberesterase unter Spornbildung; sie ist daher mit den beiden Esterasen vom Schwein immunologisch verwandt, aber nicht identisch. - Das aktive Zentrum der Carboxylesterasen ist an der Bildung des Antigen-AntikörperKomplexes nicht beteiligt.

Immunochemical studies (double diffusion after OUCHTERLONY, immunoelectrophoresis) are reported on three highly purified carboxylesterases (EC 3.1.1.1) of different origin (pig liver, pig kidney and bovine liver). Antisera to the pig liver and pig kidney enzymes were obtained by the immunisation of rabbits. Pig liver esterase was immunologically homogeneous, while the pig kidney esterase still contained traces of at least two contaminating compounds. In the Ouchterlony test, pig liver and pig kidney esterase are immunologically identical, but they show quarititative differences in the precipitation test with increasing concentrations of antigen. Bovine liver esterase gives trailing spurs in the comparative double diffusion test with antiserum to pig liver esterase; it is therefore related to but not indentical with the two pig esterases. The active centre of the carboxylesterases is not involved in the formation of the antigen-antibody complex.

In den vergangenen Jahren haben wir drei hochgereinigte Carboxylesterasen (EC 3.1.1.1) aus Schweineleber (1), Schweineniere $(2,3)$ und Rinderleber (4) isoliert. Die drei Präparationen stimmen in vielen Eigenschaften überein (Verhalten bei Säulenchromatographie, Ammoniumsulfatfällung, Molekulargewịchț, Zahl der aktiven Zentren, pH-Optimum u. a.). Andererseits haben wir einige Unterschiede beobachțet, z. B. in den

1) Aus der Doktorarbeit von cand. med. Peter Harn.
Wechselzahlen gegen verschiedene Substrate, im Verhalten gegen einige Inhibitoren und in der Stabilität bei niedrigen pH-Werten. Diese Beobachtungen werfen die Frage auf, inwieweit die drei Enzymproteine identisch sind. Zur Klärung dieses Problems bieten sich neben Methoden der Proteinchemie immunologische Verfahren an. In der vorliegenden Arbeit wird über einige Ergebnisse zur immunologischen Reinheit und Verwandtschaft von Carboxylesterasen verschiedener Herkunft berichtet. 